\title{
Klasifikasi Keadaan Mata Berdasarkan sinyal EEG menggunakan Extreme Learning Machines
}

\author{
Ersa Christian Prakoso ${ }^{\# 1}$, Untari Novia Wisesty ${ }^{* 2}$, Jondri ${ }^{\# 3}$ \\ \# School of Computing, Telkom University \\ Jl. Telekomunikasi No. 01, Terusan Buah Batu, Bandung, Jawa Barat, Indonesia \\ ${ }^{1}$ ersachristian@students.telkomuniversity.ac.id \\ ${ }^{2}$ untari.n.wisesty@gmail.com
}

\begin{abstract}
Electroencephalography signal or EEG signal is one of biosignals that currently being hot topic for research. EEG signal has many benefits including detection of epilepsy from patients, sleep disorders, or an input for a computer application. A kind of input that can be used based on EEG signal is eye state. However, An Classification with a suffice performance is needed for that purpose. Therefore, writer will do a research which will implement a new learning method for Artificial Neural Network called Extreme Learning Machine for classifying eye state based on EEG signal. Dataset that will be used for training and testing were donated by Oliver Roesler and combined with dataset from Repository University of California, Irvinel (UCI). There are 7 corpora which consist of EEG records of 4 differents people. Based on system testing, we can draw a conclusion that ELM classifier can be used to classify eye-state based on ELM with good performance. Tested system can achieve $97,95 \%$ accuracy and only need 0,81 second of training if the corpus is used separately. However, if all the corpora are used together as one big corpus, ELM classifier can only achieved 78,94\% accuracy with 5,71 seconds training time.
\end{abstract}

Keywords : Classification, Electroencephalography (EEG), Extreme Learning Machine (ELM).

\begin{abstract}
Abstrak
Electroencephalography atau sinyal EEG adalah salah satu biosignal yang marak menjadi topik penelitian saat ini. Sinyal EEG memiliki banyak manfaat seperti pendeteksian epilepsi, gangguan tidur, atau input dalam aplikasi komputer. Salah satu input yang dapat dideteksi berdasarkan sinyal EEG adalah keadaan mata. Namun untuk digunakan sebagai input dalam aplikasi diperlukan klasifikasi dengan performansi yang memadai. Oleh karena itu penulis akan dilakukan penelitian dimana salah satu metode pembelajaran Jaringan Syaraf Tiruan yaitu Extreme Learning Machine (ELM) akan diimplementasikan untuk mengklasifikasikan kondisi mata berdasarkan sinyal EEG. Dataset yang digunakan untuk melatih dan menguji model adalah dataset eye-state yang didonasikan oleh Oliver Roesler digabung dengan dataset yang berasal dari website repository Universitas of California, IrvineI (UCI) . Terdapat 7 corpus yang terdiri dari perekaman EEG yang dilakukan kepada 4 orang berbeda, lalu ditambahkan 1 corpus yang merupakan penggabungan seluruh corpus lain. Dari hasil pengujian yang dilakukan disimpulkan bahwa ELM dapat digunakan untuk klasifikasi keadaan mata dengan akurasi mencapai 97,95\% dengan waktu latih hanya 0,81 detik jika masing-masing data digunakan secara terpisah, sedangkan penggabungan keseluruhan dataset hanya mencapai akurasi 78,94\% dengan waktu latih 5,71 detik.
\end{abstract}

Kata Kunci : Klasifikasi, Electroencephalography (EEG), Extreme Learning Machine (ELM). 
Ersa Christian Prakoso et.al.

\section{PENDAhULUAN}

Akhir-akhir ini riset tentang bagaimana cara otak manusia bekerja semakin marak dan menjadi topik hangat untuk diperbincangkan dalam biomedik. Umumnya penelitian dilakukan dengan menganalisa sinyal yang dikeluarkan dari tubuh manusia, atau yang disebut biosignal. Berbagai metode dan alat diciptakan untuk menangkap sinyal yang ada dari tubuh manusia, antara lain adalah EEG, EOG, ECG, EMG, dan sebagainya.

Salah satu biosignal yang paling umum digunakan adalah EEG atau Electroencephalography. EEG paling umum digunakan sebagai metode untuk mendeteksi epilepsi. Namun dalam perkembangannya, EEG juga digunakan untuk mendeteksi berbagai hal seperti gangguan tidur, brain death, serta sebagai input dalam aplikasi komputer. Untuk digunakan sebagai brain-computer interface, selain diperlukan sistem klasifikasi dengan akurasi yang memadai, sistem harus dapat mengeluarkan hasil dengan cepat agar tidak delay antara input dengan respon yang akan dilakukan komputer terutama jika digunakan untuk sistem real-time.

Salah satu riset yang telah dilakukan adalah bagaimana perubahan EEG terhadap pergerakan mata manusia. Kesimpulan yang didapat adalah perbedaan terbesar dari kondisi saat mata tertutup dan terbuka adalah kekuatan dari kedua kondisi, kekuatan di mata saat mata tertutup adalah lebih besar daripada saat mata terbuka [1]. Hasil dari riset tersebut dapat digunakan untuk fitur dalam klasifikasi 2 status yang ada. Namun tidak banyak riset lanjutan yang mencoba menciptakan sistem klasifikasi untuk eye-state [2].

Salah satu riset yang telah dilakukan mencoba menggunakan berbagai metode yang ada untuk menklasifikasikan kedua kondisi tersebut berdasarkan sinyal EEG yang didapat [2]. K-star dapat menghasilkan akurasi yang tinggi pada kasus ini yaitu hingga mencapai $97 \%$ tanpa perlu dilakukan preprocessing pada data EEG. Namun terdapat kelemahan yang cukup fatal dari $K$-star yaitu sangat lambat untuk mengeluarkan output, seperti halnya instance-based learner lain. Pada data ini diperlukan waktu hingga 38 menit untuk mendapatkan label hasil pengujian $K$-star dari keseluruhan data yang ada, sangat tidak bagus untuk digunakan dalam brain-computer interface yang bersifat real-time.

Jaringan Syaraf Tiruan (JST) adalah salah satu metode yang umum digunakan untuk kasus regresi maupun klasifikasi. Namun perkembangannya mengalami kemacetan. Pada tahun 2006, muncul konsep yang secara filosifi meniru cara belajar dari otak manusia, yaitu Extreme Learning Machine (ELM) [3]. Berbeda dengan JST dan Deep Learning, ELM menganggap neuron dari hidden layer tidak perlu di-tuning. Selain itu karena tidak perlu melakukan iterasi dalam data seperti Backpropagation, ELM dapat memangkas waktu training menjadi jauh lebih cepat [3]. Deep Learning sendiri telah diuji untuk kasus klasifikasi emosi berdasarkan sinyal EEG dan didapatkan performansi yang cukup baik hingga mencapai lebih dari 80\% [4]. Riset lain telah dilakukan dan terbukti bahwa dalam kasus klasifikasi emosi menggunakan EEG, salah satu variasi ELM, yaitu GELM mampu menyaingi performansi dari Support Vector Machine dengan waktu training jauh lebih singkat. Selain itu karena modelnya hanya berupa perkalian matriks JST umumnya dapat mengeluarkan hasil yang cepat dari input yang ada.

Dalam penelitian kali ini, penulis ingin mengimplementasikan konsep Extreme Learning Machine untuk pengklasifikasian eye-state berbasis EEG. Penulis ingin membuktikan bahwa dengan waktu training yang jauh lebih cepat, ELM dapat memberikan performansi yang baik.

\section{TINJAUAN PUSTAKA}

\section{A) Electroenchephalography}

Selama otak bekerja, neuron dalam otak akan menghasilkan suatu aktivitas elektrik tertentu. Electroenchephalography adalah suatu kegiatan untuk merekam aktivitas elektrik spontan dari otak dalam periode tertentu [5]. Perekaman dilakukan menggunakan alat yang dinamakan Electroenchapalogram (EEG). Penggunaan alat EEG dilakukan dengan menempelkan elektrode EEG ke bagian-bagian tertentu dari kepala.

Alat yang digunakan dalam perekaman adalah Emotiv Epoc Headset yang dikembangkan oleh perusahaan EMOTIV dan dijual bebas untuk umum. Alat berikut memiliki daya sampling sebanyak $128 \mathrm{~Hz}$ yang berarti dalam 1 detik, headset dapat merekam hingga 128 nilai dari masing-masing channel. Rentang nilai yang dihasilkan dari tiap channel berkisar antara 0 hingga 9600. Seperangkat Emotiv Epoc Headset dijual antara 
US\$400 hingga US\$900 tergantung kelengkapannya. Emotiv Epoc Headset memiliki 14 channel yang penempatannya dapat dilihat pada gambar berikut:

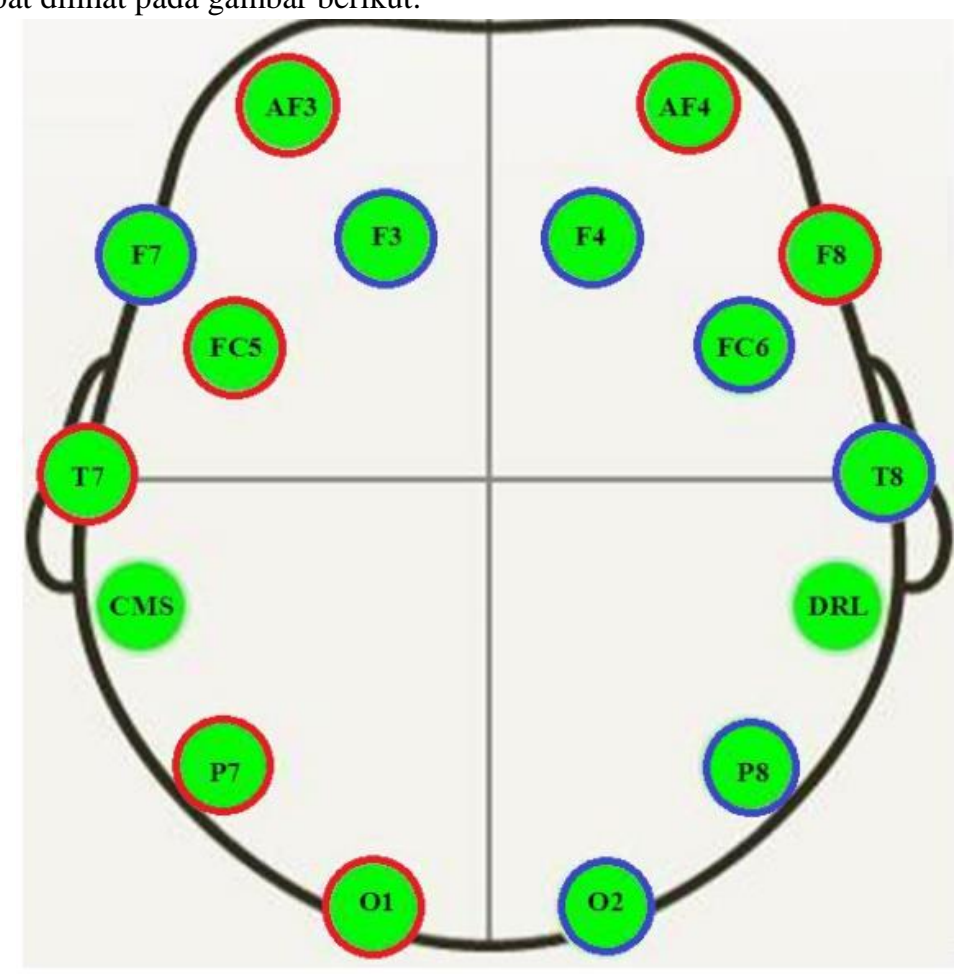

Fig. 1 Penempatan Elektrode pada dataset Eye-state [2]

Penelitian menunjukkan bahwa perbedaan terbesar dari keadaan saat mata tertutup dan terbuka adalah power. Power saat keadaan mata tertutup adalah lebih besar daripada saat mata terbuka [1]. Hal ini terlihat pada dataset eye-state yang dikeluarkan oleh Oliver Roesler [2]. Menurut dataset nilai corpus tersebut, amplitudo dari sensor F7, F3, O2, P8, T8, FC6, dan F4 menunjukkan nilai maksimum saat mata terbuka lebih besar daripada saat mata tertutup dan nilai minimumnya cenderung sama. Namun untuk sensor AF3, FC5, T7, P7, O1, F8, dan AF4 nilai minimum saat mata terbuka lebih besar daripada saat mata tertutup dan nilai maksimumnya cenderung tetap.

Ting Wang pada salah satu risetnya [10] melakukan ekstraksi fitur dari seluruh nilai secara temporal dan didapatkan first-order feature dan second-order feature untuk dicari rata-rata dan standar deviasinya sebagai fitur baru, dan terbukti dapat membantu akurasi dari sistem klasifikasi yang digunakan.

\section{B) Artifical Neural Network}

Artifical Neural Network atau Jaringan Syaraf Tiruan (JST) merupakan salah satu upaya manusia dalam memodelkan cara berpikir manusia kedalam komputer. JST dapat diartikan sebagai proses tersebar pararel yang sangat besar yang memiliki kecenderungan untuk menyimpan pengetahuan yang bersifat pengalaman dan membuatnya siap digunakan [6]. Dalam JST pengetahuan yang didapat dipresentasikan dalam bobot koneksi antar sel syaraf yang ada (neuron). Dalam setiap neuron terjadi perhitungan sebagai berikut:

$$
y(x)=f(s(x))
$$

Dimana $\mathrm{s}(\mathrm{x})$ adalah kombinasi linear dari input $\mathrm{x}$, dengan bobot $w$ dan bias $\mathrm{b}$. 
Ersa Christian Prakoso et.al.

$$
s(x)=\sum \mathrm{w}_{\mathrm{i}} \mathrm{x}_{\mathrm{i}}+b
$$

Secara umum ANN terdiri atas 3 bagian layer, yaitu input layer, hidden layer, output layer. Jumlah dari input layer, dan output layer adalah 1, sedangkan hidden layer dapat terdiri dari 1 layer ataupun lebih tergantung dari arsitektur yang digunakan [5].

Salah satu jenis ANN yang paling simpel dan umum digunakan adalah feedforward neural network. Pada arsitektur ini, seluruh koneksi antar neuron terhubung ke neuron di layer berikutnya tanpa ada koneksi yang kembali ke layer sebelumnya.

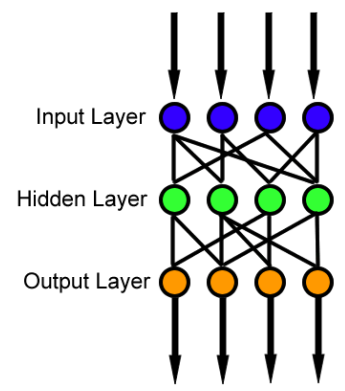

Fig. 2 Feedforward Neural Network [5]

Metode belajar paling umum yang digunakan untuk feedforward neural network adalah Backpropagation.

\section{C) Extreme Learning Machines (ELM)}

Extreme Learning Machines atau biasa disingkat ELM adalah algoritma learning yang awalnya dirancang untuk Single Layer Feedforward Neural Network (SLFN) untuk menggantikan Backpropagation. ELM menawarkan proses belajar yang ribuan kali lebih cepat dibanding Backpropagation namun dengan performansi generalisasi yang lebih baik [3].

Berbeda dengan Backpropagation yang melakukan iterasi dan mengubah nilai bobot koneksi antar seluruh neuron untuk meminilasi error, ELM membuktikan bahwa bobot dari input layer dan bias dari hidden layer dapat diberi nilai acak jika fungsi aktivasi di hidden layer terdiferensiasi.

Beberapa masalah dalam algoritma belajar BP yang dianggap perlu diperbaiki oleh ELM adalah [3]:

1) Parameter Learning rate dalam BP berpengaruh besar terhadap performansi sistem. Jika terlalu kecil, maka proses belajar akan berjalan sangat lambat, sedangkan jika terlalu besar, algoritma menjadi tidak stabil dan sulit mencapai konvergen.

2) BP cenderung terjebak dalam lokal minima.

3) Perlu metode khusus untuk mencegah over-fit.

4) Gradient-based Learning seperti BP sangat menghabiskan waktu untuk kebanyakan aplikasi.

Sebuah ELM dengan Hidden node dan fungsi aktifiasi g dapat dimodelkan sebagai berikut:

$$
\begin{gathered}
\beta^{T} H=T \\
\text { Dimana } H=\left[\begin{array}{ccc}
g\left(w_{1} \cdot x_{1}+b_{1}\right) & \cdots & g\left(w_{1} \cdot x_{N}+b_{1}\right) \\
\cdots & \cdots & \cdots \\
g\left(w_{K} \cdot x_{1}+b_{K}\right) & \cdots & g\left(w_{K} \cdot x_{N}+b_{K}\right)
\end{array}\right]_{K * N}
\end{gathered}
$$




$$
\beta=\left[\begin{array}{c}
\beta_{1}^{T} \\
\cdot \\
\cdot \\
\beta_{K}^{T}
\end{array}\right]_{K * m} \quad T=\left[t_{1}, \ldots, t_{n}\right]_{m * N}
$$

$w j=(w j 1, w j 2, \ldots, w j d)$ adalah weight input dari vektor yang menghubungkan hidden node ke-j dengan node input, dan $\beta j=(\beta j 1, \beta j 2, \ldots, \beta j m)^{T}$ adalah weight dari vektor yang menghubungkan hidden node ke-j dengan node output. Bj adalah bias dari node ke-j.

Guang-Bin Huang [3] mengungkapkan teori bahwa untuk Single Layer Feed Forward Network dengan fungsi aktivasi $\mathrm{g}: \mathrm{R} \rightarrow \mathrm{R}$ dimana fungsi tersebut infinitely differentiable, untuk sampel $\left(\mathrm{x}_{\mathrm{i}}, \mathrm{t}_{\mathrm{i}}\right)$, dimana $\mathrm{x}_{\mathrm{i}} \in$ $R^{n}, t_{i} \in R^{m}$ yang berbeda sejumlah $\mathrm{N}$, untuk segala $\mathrm{w}_{\mathrm{i}}$ dan $\mathrm{b}_{\mathrm{i}}$ dipilih secara acak dalam interval $R^{n}$ dan $R^{m}$ maka dengan probabiltas 1, terdapat output dari matriks hidden layer $\mathrm{H}$ untuk SLFN dimana $\|H \beta-T\|=0$.

Dari teori diatas maka terbukti bahwa bobot maupun bias dari hidden layer tidak perlu di-tune namun dapat dibangkitkan secara acak. Untuk nilai bobot dan bias tertentu maka untuk melatih SLFN secara sederhana dapat digambarkan sebagai mencari solusi least-squares dari sistem linear $\mathrm{H} \beta=\mathrm{T}$.

Jika jumlah hidden node sama dengan jumlah sampel yang berbeda dari data latih, maka matriks $\mathrm{H}$ adalah persegi dan dapat di-inverse, dan SLFN dapat memperkirakan sampel latih tersebut dengan error 0. Namun, untuk kebanyakan kasus, jumlah hidden node jauh lebih kecil daripada jumlah sampel data latih berbeda yang digunakan, maka $\mathrm{H}$ adalah matriks non-persegi dan solusi dengan norm terkecil dari sistem linear tersebut bisa didapat dari persamaan:

$$
\beta=\boldsymbol{H}^{+} \boldsymbol{T}
$$

$\boldsymbol{H}^{+}$adalah Moore-Penrose generalized inverse dari matriks $\mathbf{H}$.

Secara sederhana terdapat 3 langkah dalam proses latih ELM [3]:

Andaikan terdapat sebuah training set $\S=\left\{\left(x_{i}, t_{i}\right) \mid x_{i} \in R^{n}, t_{i} \in R^{m}, i=1, \ldots \ldots, n\right\}$, fungsi aktivasi $\mathrm{g}(\mathrm{x})$ dan hidden node berjumlah $\tilde{\mathrm{N}}$,

1. Tetapkan nilai bobot input $\mathrm{w}_{\mathrm{i}}$ dan bias $\mathrm{b}_{\mathrm{i}}, i=1, \ldots \ldots, \tilde{\mathrm{N}}$.

2. Hitung matriks $\mathbf{H}$ output dari hidden layer.

3. Hitung bobot dari output $\beta$

$$
\beta=\boldsymbol{H}^{+} \boldsymbol{T}
$$

$\operatorname{dimana} T=\left[t_{1}, \ldots, t_{N}\right]^{T}$

Orthogonal Projection dapat digunakan untuk menghitung Moore-Penrose, $\boldsymbol{H}^{+}=\left(\boldsymbol{H}^{\boldsymbol{T}} \boldsymbol{H}\right)^{-\mathbf{1}} \boldsymbol{H}^{\boldsymbol{T}}$ jika $\boldsymbol{H}^{\boldsymbol{T}} \boldsymbol{H}$ nonsingular, atau $\boldsymbol{H}^{+}=\boldsymbol{H}^{T}\left(\boldsymbol{H}^{T}\right)^{-1}$ jika $\boldsymbol{H}^{T}$ nonsingular. Menurut ridge regression theory, disarankan untuk menambahkan bilangan positif ke diagonal $\boldsymbol{H}^{\boldsymbol{T}} \boldsymbol{H}$ atau $\boldsymbol{H}^{\boldsymbol{T}}$ pada penghitungan bobot $\beta$ sehingga model menjadi lebih stabil dan memiliki performansi generalisasi yang lebih baik $[8,14]$. Sehingga penghitungan bobot $\beta$ dapat ditulis sebagai berikut:

$$
\beta=H^{T}\left(\frac{I}{C}+H H^{T}\right)^{-1} T
$$

Atau,

$$
\beta=\left(\frac{I}{C}+H^{T} H\right)^{-1} H^{T} T
$$


Ersa Christian Prakoso et.al.

dimana I adalah matriks identitas sebesar matriks persegi $\boldsymbol{H H}^{\boldsymbol{T}}$ ataupun $\boldsymbol{H}^{\boldsymbol{T}} \boldsymbol{H}$, dan $\mathrm{C}$ adalah parameter yang ditentukan oleh user. Untuk sistem dengan jumlah hidden neuron lebih sedikit dari jumlah baris data latih yang digunakan disarankan menggunakan persamaan (9) sedangkan untuk kasus sebaliknya disarankan menggunakan persamaan (8) $[8,14]$.

\section{D) Moore-Penrose generalized inverse}

Solusi dari sistem linear $\mathrm{Ax}=\mathrm{y}$, dimana A mungkin singular atau tidak persegi, dapat dibuat sederhana dengan menerapkan Moore-Penrose generalized inverse [3]. Matriks G dengan ordo n x m adalah MoorePenrose generalized inverse untuk matriks A berordo $\mathrm{n} \times \mathrm{m}$ jika:

$$
A G A=A, G A G=G,(A G)^{T}=A G,(G A)^{T}=G A .
$$

Solusi Moore-Penrose generilized inverse bisa didapatkan menggunakan berbagai metode seperti Single Value Decomposition (SVD), dan Orthogonal Projection

\section{E) Penulisan Terkait}

Oliver Roesler [2] adalah yang pertama mengangkat kasus klasifikasi keadaan mata sekaligus membuat data yang digunakan penulis. Dataset EEG terdiri atas 15 atribut dimana 14 atribut adalah nilai dari masing-masing elektrode dan 1 atribut keadaan mata. Data disimpan secara terurut untuk memungkinkan analisa dependansi temporal. Menurut data berikut, amplitudo dari sensor F7, F3, O2, P8, T8, FC6, dan F4 menunjukkan nilai maksimum saat mata terbuka lebih besar daripada saat mata tertutup dan nilai minimumnya cenderung sama. Namun untuk sensor AF3, FC5, T7, P7, O1, F8, dan AF4 nilai minimum saat mata terbuka lebih besar daripada saat mata tertutup dan nilai maksimumnya cenderung tetap. Untuk eksperimen klasifikasi, digunakan weka toolkit dengan parameter standar. Classifier umum seperti naive bayes, ANN, SMO, dan logistic regression menghasilkan performansi yang buruk dengan error lebih dari 30\%. Algoritma Decisian Tree menghasilkan performansi lebih baik hingga sekitar 15\%. Performansi terbaik didapat instance-based learner seperti KStar dengan error hanya mencapai 3,2\%. Kelemahan dari instance-based learner ini adalah waktu testing yang lama. Untuk melakukan testing pada keseluruhan corpus pada paper terkait dibutuhkan waktu kurang lebih 38 menit sehingga perlu menjadi pertimbangan jika digunakan untuk real-time system.

Oliver Roesler melakukan riset lanjutan yang menguji pengaruh dari alat rekam EEG terhadap performansi sistem klasifikasi keadaan mata [9]. Terdapat 3 alat yang digunakan untuk perekaman EEG yaitu MindWave, Emotiv EPOC, dan BrainAmp Standart. Perbedaan terbesar dari alat-alat tersebut adalah jumlah channel dan Sampling rate masing-masing alat. MindWave memiliki hanya 1 channel namun dengan sampling rate cukup tinggi yaitu $512 \mathrm{~Hz}$, dan dijual umum dengan harga $80 \$$. Emotiv EPOC adalah alat rekam lain selain MindWave yang dijual umum, namun dengan harga yang lebih tinggi yaitu sekitar 700\$. Emotiv EPOC memiliki 14 channel dengan sampling rate $128 \mathrm{~Hz}$. Alat terakhir yaitu BrainAmp Standart tidak dijual untuk umum, karena harganya yang cukup mahal hingga mencapai 60000€. BrainAmp Standart memiliki 32 channel dengan sampling rate mencapai $1 \mathrm{kHz}$. Dilakukan pengujian pengaruh alat masing-masing terhadap klasifikasi keadaan mata, namun khusus BrainAmp hanya digunakan 12 channel saja untuk menguji apakah pada jumlah channel yang sama, hasil yang didapat akan sama dengan alat lain atau tidak. Hasilnya, BrainAmp memiliki error rate yang paling tinggi. Hal ini tidak dikarenakan jumlah channel yang hanya 1, karena telah diuji klasifikasi menggunakan Emotiv EPOC dengan hanya 1 channel namun dapat menghasilkan akurasi yang jauh lebih baik, sedangkan Error rate Emotiv EPOC sendiri dengan menggunakan 14 channel hanya sedikit tertinggal dibawah BrainAmp Standart yang menggunakan 12 channel yaitu dari $11,1 \%$ menadji $16,5 \%$. Perlu diingat bahwa harga Emotiv EPOC berada jauh dibawah alat profesional BrainAmp Standart namun dengan performansi yang tidak terpaut jauh, sehingga Emotiv EPOC sangat cocok untuk digunakan sebagai Brain-Computer Interface yang dapat digunakan secara umum, hanya perlu dikembangkan sistem yang dapat menerjemahkan input Emotiv EPOC

Guang-Bin Huang [7] melakukan perbandingan antara Extreme Learning Machine (ELM) dengan Support Vector Machine (SVM) dan Least Squares- Support Vector Machine (LS-SVM). Masing-masing metode diuji dengan berbagai dataset untuk kasus binary classification, multi-class classification, dan Regression. Pada sebagian besar kasus ELM dapat menyaingi performansi SVM maupun LS-SVM dengan waktu training yang 
lebih singkat. Contohnya untuk dataset Wine, ELM mampu mencapai akurasi $98.57 \%$ dengan waktu latih 0.0206 detik dibanding SVM yang mencapai akurasi 98.37 dengan waktu latih 0.075 detik dan LS-SVM yang hanya mencapai akurasi 97.63 dengan waktu latih 1.82 detik. Contoh lain adalah pada dataset Colon, ELM mencapai akurasi $90.63 \%$ dibanding SVM dan LS-SVM dengan akurasi 84.38\% dan 87.5\%, dengan masingmasing waktu training 0.001 detik, 0.0462 detik, dan 0.0469 secara berurutan. Melihat waktu latih yang sangat singkat namun dengan akurasi yang lebih baik dari SVM, penulis melihat ELM sebagai alternatif yang dapat dicoba untuk classifier sinyal EEG.

Ting Wang [10] menggunakan dataset yang sama dengan yang digunakan pada paper 1. Metode yang digunakan sebagai classifier adalah Neural Network dengan menerapkan Increasing Input Dimension (ITID) dimana input dari learning akan bertambah seiring berjalannya proses learning. Pengujian dilakukan dengan 4 skenario. Skenario pertama adalah penggunaan temporal feature extraction untuk mendapatkan first-order feature dan second-order feature, penghitungan standar deviasi dan rata-rata sebagai fitur baru, lalu dilakukan pengurutan input untuk ITID. Pengurutan fitur input ini adalah proses khusus yang hanya dilakukan dalam sistem berbasis Incremental Attribute Learning. Pendekatan kedua adalah menggunakan Temporal Feature Extraction, lalu menghitung standar deviasi dan rata-rata sebagai fitur baru seperti skenario 1, namun dilakukan pengurutan ulang input dan mempertahankan urutan lama dari dataset. Skenario 3 menggunakan Batch-training dengan menggunakan fitur dari second-order feature. Skenario 4 adalah Batch-training, tanpa adanya temporal feature extraction, sehingga dataset digunakan secara langsung untuk training. Hasil dari tiap pendekatan secara terurut adalah error sebesar 27,4573\%; 27,4793\%;29,5046\%;30,6328\%.

Jia-Yi Zhu [11] memperkenalkan variasi baru dari ELM yaitu GELM dengan tujuan menyeimbangkan konsistensi properti dari data berdimensi besar, dan mendorong keluaran dari sampel di kelas yang sama menjadi semirip mungkin. Algoritma tersebut diterapkan dalam kasus klasifikasi emosi berdasarkan EEG dimana emosi dibagi menjadi 3 kelas yaitu positif, negatif, dan netral. Performansi keseluruhan dari GELM mampu menyaingi Support Vector Machine (SVM) dengan rata-rata 80,25\% dan standar deviasi $\pm 11,92 \%$ dibanding $76,62 \%$ dan standar deviasi $\pm 13,12 \%$.

Yong Peng [12] memperkenalkan variasi lain yang baru untuk ELM dengan nama MRELM. GELM hanya memaksa output dari sampel kelas yang sama agar menjadi mirip. Namun dalam studi lebih lanjut, performansi learning dapat ditingkatkan jika struktur geometri dari data dieksploitasi. Algoritma tersebut diterpakan dalam kasus yang sama dengan paper nomor 3, yaitu klasifikasi emosi berdasarkan EEG dengan membagi kelas emosi menjadi 3, positif, negatif, dan neutral. Secara keseluruhan performansi MRELM mampu menyaingi GELM maupun SVM dengan akurasi $81,01 \%$ dan standar deviasi $\pm 12,24 \%$.

\section{METODE PENELITIAN}

\section{A) Pengumpulan Data}

Seluruh datasets yang akan digunakan didapatkan dari donasi oleh Oliver Roesler dan disatukan dengan dataset eye-state dari website Repository University of California, Irvine (UCI) dengan URL:https://archive.ics.uci.edu/ml/datasets/EEG+Eye+State yang dibuat oleh orang yang sama. Dataset terdiri atas 7 corpus dimana masing-masing corpus merupakan hasil perekaman selama kurang lebih 2 menit dari 4 orang yang berbeda. Masing-masing orang menghasilkan 2 corpus kecuali orang terakhir. Terdapat kamera yang memeriksa keadaan mata dari pelaku yang kemudian akan ditambahkan kedalam dataset sebagai target. Dataset corpus memiliki 15 feature, 14 atribut nilai real EEG dari channel AF3, F7, F3, FC5, T7, P7, O1, O2, P8, T8, FC6, F4, F8, AF4 dan 1 nilai integer target keadaan mata. 0 menandakan keadaan mata terbuka dan 1 menandakan keadaan mata tertutup. Seluruh keadaan saat mata belum sepenuhnya tertutup dikategorikan sebagai mata terbuka.

\section{B) Alur sistem Keseluruhan}

Berikut adalah Flowchart dari sistem klasifikasi keadaan mata berdasarkan EEG menggunakan Extreme Learning Machine: 


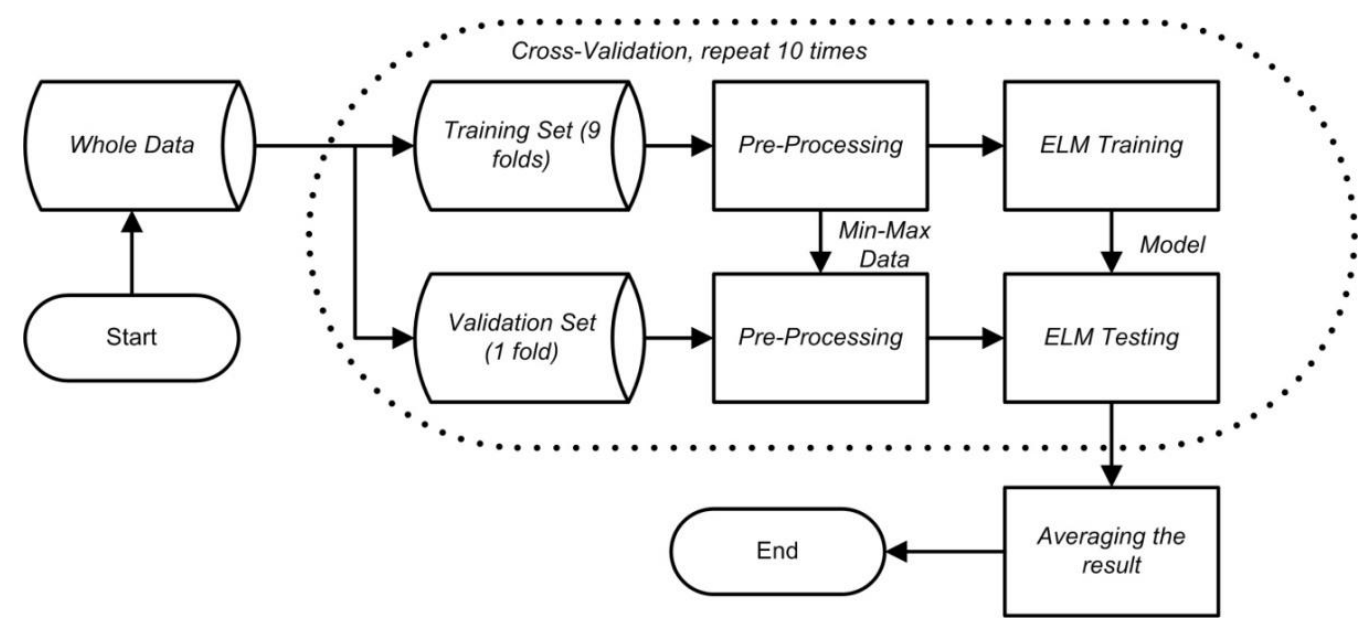

Fig. 3 Flowchart Pengujian Sistem

Secara umum terdapat 4 proses utama dari sistem klasifikasi yang dibuat yaitu: Cross Validation, Preprocessing, Proses Training ELM, dan klasifikasi dengan ELM untuk data uji.

\section{1) Data latih dan data Uji}

Dataset akan dibagi menjadi data latih dan data uji menggunakan teknik 10-fold cross validation. Berikut adalah contoh baris fitur yang menjadi input untuk sistem serta target atau keluarannya:

TABLE I

CONTOH INPUT DAN TARGET SISTEM

\begin{tabular}{|c|c|c|c|c|c|}
\hline \multicolumn{5}{|c|}{ Input } & \multirow{2}{*}{ Target } \\
\hline $\mathrm{X} 1$ & $\mathrm{X} 2$ & $\mathrm{X} 3$ & $\ldots \ldots$ & $\mathrm{X} 14$ & \\
\hline 4329.23 & 4009.23 & 4289.23 & $\ldots \ldots$ & 4393.85 & 0 \\
\hline 4292.31 & 4005.64 & 4246.67 & $\ldots \ldots$ & 4345.13 & 1 \\
\hline 4317.44 & 4010.77 & 4258.46 & $\ldots \ldots$ & 4376.41 & 0 \\
\hline$\ldots$ & $\ldots$. & $\ldots$. & $\ldots \ldots$ & $\ldots$. & $\ldots$. \\
\hline 4302.56 & 4006.67 & 4249.74 & $\ldots \ldots$ & 4375.9 & 0 \\
\hline
\end{tabular}

2) Pre-Processing

Tahap Pre-Processing yang dilakukan adalah normalisasi data menjadi berkisar antara 0 hingga 1 . Proses normalisasi dilakukan dengan persamaan berikut:

$$
\mathrm{X}^{\prime}=\frac{X-X_{\text {min }}}{X_{\max }-X_{\min }}
$$

Dimana $\mathrm{X}^{\prime}$ adalah nilai baru fitur dalam domain normalisasi, $X$ adalah nilai sebelum normalisasi, $X_{\min }$ adalah nilai terkecil dari seluruh data yang akan dinormalisasi, dan $X_{\max }$ adalah nilai terbesar dari seluruh data yag akan dinormalisasi 


\section{3) Sistem Klasifikasi ELM}

Dalam kasus klasifikasi keadaan mata ini, akan digunakan Extreme Machine Learning (ELM) sebagai classifier. ELM adalah sebuah Neural Network dengan 1 Hidden Layer dengan menggunakan dengan algoritma Least Square based untuk proses latih [13]. Berikut adalah flowchart proses latih dari model ELM:

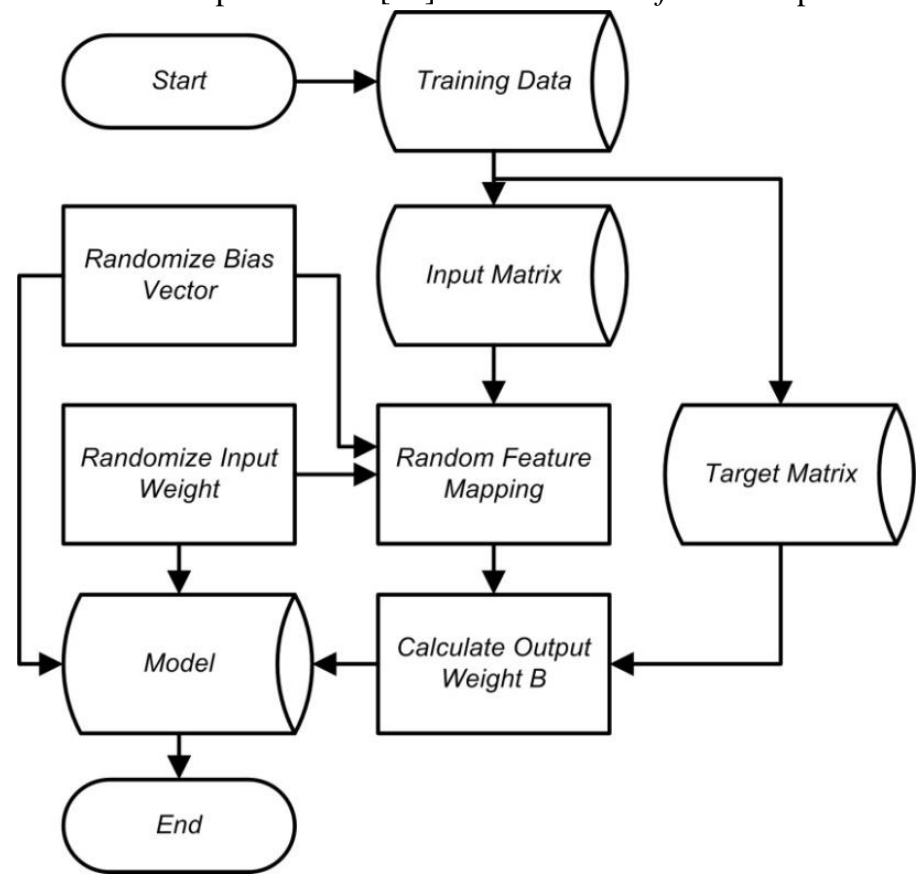

Fig. 4 Flowchart Proses Training ELM

Sebuah ELM dengan 1 Hidden Layer dan fungsi aktivasi $g$ dapat dimodelkan sebagai berikut:

$$
\beta^{T} H=T
$$

Dimana:

$$
\begin{gathered}
H=\left[\begin{array}{ccc}
g\left(w_{1} \cdot x_{1}+b_{1}\right) & \ldots & g\left(w_{1} \cdot x_{N}+b_{1}\right) \\
\cdots & \ldots & \ldots \\
g\left(w_{K} \cdot x_{1}+b_{K}\right) & \cdots & g\left(w_{K} \cdot x_{N}+b_{K}\right)
\end{array}\right]_{K * N} \\
\beta=\left[\begin{array}{c}
\beta_{1}^{T} \\
\cdot \\
\cdot \\
\beta_{K}^{T}
\end{array}\right]_{K * m}, T=\left[t_{1}, \ldots, t_{n}\right]_{m * N}
\end{gathered}
$$

$w j=(w j 1, w j 2, \ldots, w j d)$ adalah weight input dari vektor yang menghubungkan hidden node ke-j dengan node input, dan $\beta j=(\beta j 1, \beta j 2, \ldots, \beta j m)^{T}$ adalah weight dari vektor yang menghubungkan hidden node ke-j dengan node output. $\mathrm{Bj}$ adalah bias dari node ke-j.

Matriks Target akan menggunakan one hot encoding dimana kelas yang menjadi target akan diberi nilai 1, dan sisanya akan diberi nilai -1. Weight dari $\beta$ dapat diestimasikan [14]:

$$
\beta=\arg _{\beta} \min \left\|\beta^{T} H-T\right\|=H^{+} T=\left(\frac{I}{C}+H^{T} H\right)^{-1} H^{T} T
$$


Ersa Christian Prakoso et.al.

Jika digambarkan dalam bentuk Neural Network, berikut adalah arsitektur dari ELM yang akan digunakan:

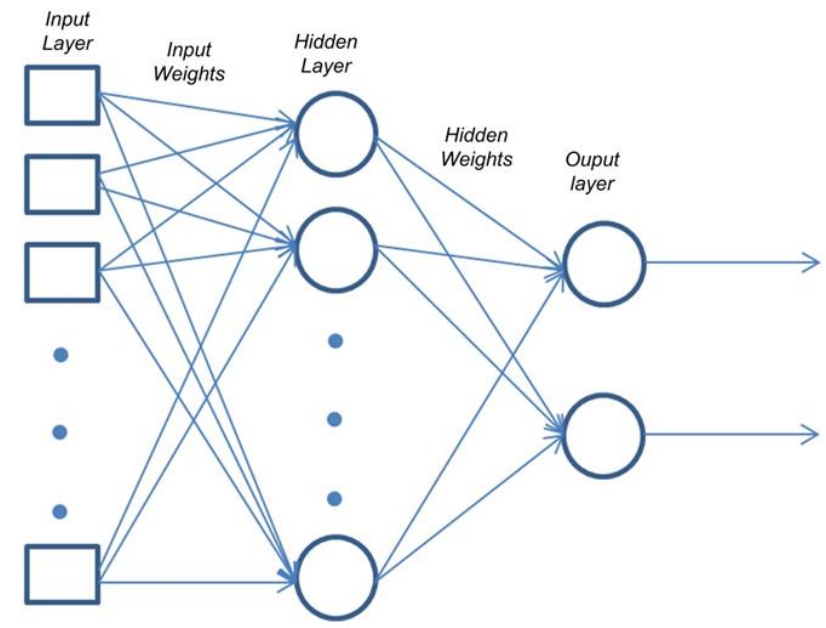

Fig. 5 Penggambaran Model dalam arsitektur NN

Nilai weight yang telah didapat kemudian dapat digunakan untuk klasifikasi dengan melakukan pengalian Matriks dari Input Weight, penambahan Bias, hingga Hidden Weight. Karena kasus keadaan mata merupakan binary classification dan digunakan 2 output neuron. Setiap output neuron mewakili masing-masing kelas, jika nilai yang keluar pada output neuron 0 lebih besar dari output neuron 1 maka baris data tersebut ditentukan sebagai kelas 0 , begitu pula sebaliknya.

\section{C) Parameter Performansi}

Parameter performansi dari sistem klasifikasi ini adalah akurasi dari sistem, sensitivity, specificity dan waktu latih model. Semakin tinggi akurasi maka performansi sistem semakin baik sedangkan semakin rendah waktu latih, semakin baik. Akurasi dari sistem didapat dari persamaan:

$$
\text { Akurasi }=\frac{\text { Jumlah klasifikasi yang benar }}{\text { Total Data yang diklasifikasi }} * 100 \%
$$

Sensitivity sistem didapat dari persamaan: (diasumsikan kelas 1 sebagai True Positive)

$$
\text { Sensitivity }=\frac{\text { True Positive }}{\text { True Positive }+ \text { False Negative }} * 100 \%
$$

Specificity sistem didapat dari persamaan: (diasumsikan kelas 1 sebagai True Positive)

$$
\text { Specificity }=\frac{\text { True Negative }}{\text { True Negative }+ \text { False Positive }} * 100 \%
$$




\section{HASIL DAN ANALISIS}

\section{A) Tujuan Pengujian}

Tujuan dari pengujian yang akan dilakukan adalah sebagai berikut:

1. Menganalisis pengaruh jumlah hidden neuron terhadap akurasi dan waktu latih sistem.

2. Menganalisis pengaruh nilai $\mathrm{C}$ terhadap akurasi dan waktu latih sistem.

3. Menganalisis pengaruh fungsi aktivasi terhadap akurasi dan waktu latih sistem.

4. Menganalisis perbedaan tiap data saat diklasifikasikan dengan sistem.

\section{B) Skenario Pengujian}

Berikut adalah skenario parameter yang akan diuji untuk mengukur performansi dari sistem klasifikasi:

1. Jumlah Hidden Neuron

Sistem ELM hanya menggunakan 1 hidden layer, namun Jumlah Hidden Neuron mempengaruhi seberapa besar matriks dari ELM feature Mapping, yang secara teori dengan jumlah cukup besar dapat menghasilkan matriks output layer yang memiliki error $=0$ terhadap data latih [3]. Diuji perubahan jumlah neuron dari 100 hingga 1000 dengan interval +100 .

2. Nilai C

Sistem ELM menerapkan teori ridge regression dengan menambahkan konsanta 1/C ke diagonal Random Feature Mapping, yang akan meningkatkan kestabilan dari model yang dihasilkan saat proses latih [7] . Nilai $\mathrm{C}$ akan diuji dari 0,1 hingga $1 \mathrm{E}+17$ dengan interval $* 10$ dan nilai 0 . Nilai 0 berarti tidak ditambahkan nilai konstan apapun.

3. Fungsi Aktivasi

Hidden Neuron pada ELM dapat menggunakan berbagai jenis fungsi aktivasi asalkan merupakan nonlinier piecewise continuous function. Fungsi aktivasi yang berbeda akan memberikan matriks ELM Feature Mapping yang berbeda juga, sehingga dapat mempengaruhi tahap penyelesaianleast-square problem. Pada pengujian diuji menggunakan fungsi sigmoid, dan fungsi radial basis.

4. Data latih dan data uji

Data yang akan digunakan adalah masing-masing corpus yang berjumlah 7 ditambah dengan corpus yang merupakan penggabungan dari keseluruhan corpus yang lain. Setiap orang memiliki ciri EEG yang berbeda, baik dari variansi, nilai maksimum, nilai minimum pada kondisi tertentu dsb. Oleh karena itu perlu diuji keefektifan model yang ada untuk orang yang berbeda.

Seluruh skenario akan dikombinasikan untuk melihat pengaruh parameter di tiap corpus yang berbeda, dan mendapatkan parameter terbaik untuk masing-masing corpus. Seluruh corpus akan diberlakukan 10-fold cross validation dan diulang sebanyak 5 kali dan dirata-ratakan. Selain itu untuk meminimalkan keacakan dari hasil yang dihasilkan sistem, pada setiap kombinasi parameter dengan jumlah hidden neuron yang sama akan menggunakan 5 matriks input weight yang sama yang telah dibangkitkan terlebih dahulu.

Berikut adalah spesifikasi masing-masing data yang akan digunakan dalam sistem:

\section{C) Spesifikasi Data}

Berikut adalah spesifikasi dari setiap corpus yang akan digunakan untuk proses latih dan uji pada sistem ELM yang ada:

TABLE II

SPESIFIKASI DATA YANG DIGUNAKAN

\begin{tabular}{|c|c|c|c|}
\hline \multirow{2}{*}{ Data } & \multirow{2}{*}{ Jumlah Baris Data } & \multicolumn{2}{|c|}{ Persentase Kelas(\%) } \\
\cline { 3 - 4 } & & 0 & 1 \\
\hline $1-1$ & 15475 & 49,03 & 50,97 \\
\hline $1-2$ & 15483 & 63,72 & 36,28 \\
\hline $2-1$ & 15483 & 56,20 & 43,80 \\
\hline $2-2$ & 15479 & 48,34 & 51,66 \\
\hline
\end{tabular}


Ersa Christian Prakoso et.al.

\begin{tabular}{|c|c|c|c|}
$3-1$ & 15473 & 17,76 & 82,24 \\
\hline $3-2$ & 15434 & 40,57 & 59,43 \\
\hline 4 & 14976 & 55,11 & 44,89 \\
\hline Gabungan & 107803 & 47,22 & 52,78 \\
\hline
\end{tabular}

Terdapat data gabungan yang merupakan penggabungan dari keseluruhan data di atas. Data 1-1 menandakan corpus pertama oleh orang pertama, data 1-2 menandakan corpus kedua oleh orang pertama, dan seterusnya. Corpus 1, 2, dan 3 adalah corpus yang digunakan dalam penelitian Oliver Roesler [9], sedangkan corpus ke 4 adalah yang digunakan dalam Oliver Roesler [8]. Pada sebagian besar corpus persentase kelas yang ada seimbang, hanya pada corpus 3-1 kelas yang ada sangat tidak seimbang yaitu $17,76 \%$ untuk kelas 0 dan $82,24 \%$ untuk kelas 1. Nilai-nilai yang berada di luar batas yang memungkinkan di seluruh corpus dihapus, yang diakibatkan kesalahan pada alat perekaman yang digunakan.

\section{D) Hasil Pengujian}

Berikut adalah hasil pengujian dari tiap skenario yang ada:

\section{Jumlah Hidden Neuron}

Berikut adalah tabel hasil pengujian pengaruh jumlah hidden neuron terhadap sistem klasifikasi yang dibangun dengan mengambil akurasi dan waktu latih tertinggi pada tiap parameter:

TABLE III

AKURASI SISTEM ELM PADA JUMLAH HIDDEN NEURON TERTENTU

\begin{tabular}{|c|c|c|c|c|c|c|c|c|}
\hline \multirow{2}{*}{$\begin{array}{l}\text { Jumlah } \\
\text { Hidden } \\
\text { Neuron }\end{array}$} & $1-1$ & $1-2$ & $2-1$ & $2-2$ & $3-1$ & $3-2$ & 4 & Gabungan \\
\cline { 2 - 9 } & & & 81,00 & 82,85 & 90,56 & 88,70 & 80,42 & 70,60 \\
\hline 100 & 88,70 & 93,11 & $8 k, 73$ & 73,63 \\
\hline 200 & 92,80 & 95,14 & 86,83 & 86,52 & 93,49 & 92,80 & 86,73 & 74,54 \\
\hline 300 & 94,18 & 96,06 & 89,10 & 87,32 & 94,61 & 94,18 & 88,94 & 75,01 \\
\hline 400 & 95,10 & 96,59 & 90,37 & 88,05 & 95,33 & 95,10 & 90,13 & 75,73 \\
\hline 500 & 95,79 & 96,98 & 91,37 & 88,63 & 95,96 & 95,79 & 91,01 & 76,59 \\
\hline 600 & 96,45 & 97,19 & 92,20 & 89,32 & 96,37 & 96,45 & 91,68 & 77,25 \\
\hline 700 & 96,81 & 97,43 & 93,07 & 89,87 & 96,62 & 96,81 & 92,20 & 77,94 \\
\hline 800 & 97,15 & 97,69 & 93,42 & 90,26 & 96,93 & 97,15 & 92,77 & 78,46 \\
\hline 900 & 97,40 & 97,90 & 93,92 & 90,85 & 97,11 & 97,40 & 92,96 & 78,94 \\
\hline 1000 & 97,60 & 97,95 & 94,07 & 91,03 & 97,32 & 97,60 & 93,34 & \\
\hline
\end{tabular}

TABLE IV

SENSITIVITY SISTEM ELM PADA JUMLAH HIDDEN NEURON TERTENTU

\begin{tabular}{|c|c|c|c|c|c|c|c|c|}
\hline \multirow{2}{*}{$\begin{array}{l}\text { Jumlah } \\
\text { Hidden } \\
\text { Neuron }\end{array}$} & $1-1$ & $1-2$ & $2-1$ & $2-2$ & $3-1$ & $3-2$ & 4 & Gabungan \\
\hline 100 & 86,42 & 87,74 & 69,11 & 82,56 & 99,64 & 93,21 & 72,27 & 91,83 \\
\hline 200 & 90,87 & 92,23 & 78,54 & 85,92 & 99,33 & 95,50 & 81,76 & 89,19 \\
\hline 300 & 92,73 & 93,75 & 81,96 & 86,68 & 99,20 & 96,04 & 85,12 & 87,60 \\
\hline 400 & 93,10 & 94,65 & 84,14 & 87,27 & 99,14 & 96,40 & 86,82 & 86,74 \\
\hline 500 & 93,38 & 95,16 & 86,00 & 87,72 & 99,09 & 96,94 & 87,99 & 85,91 \\
\hline 600 & 93,55 & 95,47 & 87,65 & 88,52 & 99,07 & 97,49 & 88,90 & 85,48 \\
\hline 700 & 93,53 & 95,94 & 89,16 & 89,03 & 99,03 & 97,71 & 89,64 & 85,01 \\
\hline 800 & 93,83 & 96,23 & 89,85 & 89,43 & 99,04 & 97,97 & 90,43 & 84,59 \\
\hline 900 & 93,95 & 96,51 & 90,80 & 89,98 & 99,07 & 98,20 & 90,57 & 84,43 \\
\hline 1000 & 94,07 & 96,53 & 91,09 & 90,20 & 99,12 & 98,36 & 91,09 & 84,23 \\
\hline
\end{tabular}


TABLE V

SPECIFICITY SISTEM ELM PADA JUMLAH HIDDEN NEURON TERTENTU

\begin{tabular}{|c|c|c|c|c|c|c|c|c|}
\hline $\begin{array}{l}\text { Jumlah } \\
\text { Hidden } \\
\text { Neuron }\end{array}$ & $1-1$ & $1-2$ & $2-1$ & $2-2$ & $3-1$ & $3-2$ & 4 & Gabungan \\
\cline { 2 - 9 } & 89,37 & 90,23 & 76,11 & 83,24 & 94,46 & 90,73 & 76,80 & 74,43 \\
\hline 100 & 92,54 & 93,22 & 83,93 & 86,82 & 96,12 & 94,03 & 84,68 & 76,69 \\
\hline 300 & 94,09 & 94,52 & 86,81 & 87,59 & 96,77 & 95,15 & 87,35 & 77,53 \\
\hline 400 & 94,66 & 95,27 & 88,44 & 88,29 & 97,20 & 95,90 & 88,75 & 77,87 \\
\hline 500 & 95,00 & 95,80 & 89,71 & 88,84 & 97,57 & 96,48 & 89,78 & 78,42 \\
\hline 600 & 95,18 & 96,09 & 90,77 & 89,53 & 97,81 & 97,03 & 90,56 & 79,02 \\
\hline 700 & 95,30 & 96,44 & 91,85 & 90,07 & 97,96 & 97,33 & 91,15 & 79,49 \\
\hline 800 & 95,48 & 96,80 & 92,28 & 90,46 & 98,15 & 97,62 & 91,82 & 80,01 \\
\hline 900 & 95,72 & 97,09 & 92,90 & 91,04 & 98,26 & 97,82 & 92,03 & 80,45 \\
\hline 1000 & 95,79 & 97,15 & 93,08 & 91,22 & 98,38 & 97,99 & 92,46 & 80,82 \\
\hline
\end{tabular}

TABLE VI

LAMA WAKTU LATIH SISTEM ELM PADA JUMLAH HIDDEN NEURON TERTENTU

\begin{tabular}{|c|c|c|c|c|c|c|c|c|}
\hline $\begin{array}{c}\text { Jumlah } \\
\begin{array}{c}\text { Hidden } \\
\text { Neuron }\end{array}\end{array}$ & $1-1$ & $1-2$ & $2-1$ & $2-2$ & $3-1$ & $3-2$ & 4 & Gabungan \\
\cline { 2 - 9 } & & & & & & & & \\
\hline 100 & 0,04 & 0,04 & 0,04 & 0,04 & 0,04 & 0,04 & 0,04 & 0,29 \\
\hline 200 & 0,09 & 0,09 & 0,09 & 0,09 & 0,09 & 0,09 & 0,08 & 0,63 \\
\hline 300 & 0,15 & 0,15 & 0,15 & 0,15 & 0,15 & 0,15 & 0,14 & 1,04 \\
\hline 400 & 0,21 & 0,21 & 0,22 & 0,21 & 0,21 & 0,21 & 0,20 & 1,59 \\
\hline 500 & 0,29 & 0,29 & 0,30 & 0,29 & 0,29 & 0,29 & 0,28 & 2,18 \\
\hline 600 & 0,39 & 0,38 & 0,39 & 0,38 & 0,38 & 0,38 & 0,37 & 2,82 \\
\hline 700 & 0,49 & 0,48 & 0,49 & 0,47 & 0,48 & 0,47 & 0,46 & 3,53 \\
\hline 800 & 0,61 & 0,58 & 0,60 & 0,58 & 0,58 & 0,58 & 0,56 & 4,24 \\
\hline 900 & 0,72 & 0,70 & 0,72 & 0,70 & 0,70 & 0,70 & 0,68 & 5,05 \\
\hline 1000 & 0,86 & 0,83 & 0,86 & 0,83 & 0,82 & 0,82 & 0,80 & 5,98 \\
\hline
\end{tabular}

Berdasarkan Tabel III, IV, dan V terlihat bahwa pada semakin besar jumlah hidden neuron yang digunakan pada sistem, maka akurasi, Sensitivity, dan Specificity sistem semakin meningkat. Pada data 3-1 Sensitivity pada jumlah Hidden neuron 100 paling tinggi diakibatkan kurang seimbangnya kelas dari corpus tersebut, dimana kelas 1 jauh lebih dominan. Peningkatan akurasi dari cenderung makin mengecil pada saat jumlah hidden neuron semakin besar. Contohnya pada data 1-1, terlihat bahwa peningkatan jumlah hidden neuron dari 100 ke 200 terjadi peningkatan akurasi dari 88,70\% menuju 92,80\%, namun pada jumlah hidden neuron 900 ke 1000, hanya terjadi peningkatan akurasi dari 97,40\% menjadi 97,60\%. Sedangkan untuk sensitivity dan specificity, dengan meningkatnya jumlah hidden neuron, keseimbangan antara kedua hal tersebut akan semakin baik, seperti pada data 3-1 dimana pada jumlah hidden neuron 100 sensitivity mencapai nilai tertinggi yaitu 99,64\% namun specificity hanya mencapai 94,46\%. Pada jumlah hidden neuron 1000, walaupun sensitivity mengalami penurunan kecil menjadi $99,12 \%$ namun specificity mengalam peningkatan drastis hingga 98,38\% sehingga lebih baik dalam merekognisi kedua kelas. Selain itu pada tabel VI tampak bahwa jumlah hidden neuron sangat mempengaruhi seberapa lama waktu latih yang dibutuhkan oleh sistem ELM. Semakin besar jumlah hidden neuron maka waktu latih yang dibutuhkan semakin tinggi. Peningkatan waktu latih tidak terjadi secara linear seiring semakin banyak jumlah hidden neuron, namun secara eksponensial. Contohnya pada data 1-2, peningkatan jumlah hidden neuron dari 100 ke 200 hanya 
Ersa Christian Prakoso et.al.

Klasifikasi KeadaAn Mata Berdasarkan Sinyal...

meningkatkan waktu latih dari 0,04 detik menjadi 0,09 detik, namun pada jumlah hidden neuron 900 menuju 1000 , terjadi peningkatan waktu latih dari 0,70 detik menjadi 0,83 detik.

\section{Nilai $C$}

Berikut adalah tabel hasil pengujian pengaruh jumlah hidden neuron terhadap sistem klasifikasi yang dibangun dengan mengambil akurasi dan waktu latih tertinggi pada tiap parameter:

TABLE VII

AKURASI SISTEM ELM PADA NILAI C TERTENTU

\begin{tabular}{|c|c|c|c|c|c|c|c|c|}
\hline \multirow{2}{*}{ Nilai C } & \multicolumn{7}{|c|}{ Akurasi Sistem (\%) } \\
\cline { 2 - 9 } & $1-1$ & $1-2$ & $2-1$ & $2-2$ & $3-1$ & $3-2$ & 4 & Gabungan \\
\hline 0 & 95,80 & 97,95 & 94,07 & 91,03 & 97,32 & 97,60 & 93,34 & 78,94 \\
\hline 0,1 & 84,89 & 94,44 & 68,68 & 80,80 & 90,69 & 91,10 & 81,95 & 66,57 \\
\hline 1 & 86,23 & 95,76 & 72,39 & 84,50 & 93,31 & 94,02 & 87,02 & 68,02 \\
\hline 10 & 87,96 & 96,82 & 75,93 & 86,94 & 95,29 & 95,74 & 89,87 & 69,68 \\
\hline 100 & 90,57 & 97,47 & 79,97 & 88,10 & 96,35 & 96,82 & 91,85 & 71,58 \\
\hline 1000 & 92,37 & 97,82 & 84,10 & 89,29 & 96,88 & 97,30 & 92,92 & 73,37 \\
\hline 10000 & 93,91 & 97,93 & 87,03 & 90,20 & 97,05 & 97,40 & 93,23 & 74,27 \\
\hline 100000 & 94,75 & 97,94 & 89,19 & 90,66 & 97,08 & 97,40 & 93,20 & 75,09 \\
\hline 1000000 & 95,22 & 97,95 & 90,87 & 90,71 & 97,08 & 97,44 & 93,21 & 76,06 \\
\hline 10000000 & 95,63 & 97,95 & 92,30 & 90,72 & 97,27 & 97,60 & 93,31 & 77,27 \\
\hline
\end{tabular}

TABLE VIII

STANDAR DEVIASI AKURASI SiSTEM ELM PADA NILAI C TERTENTU

\begin{tabular}{|c|c|c|c|c|c|c|c|c|}
\hline \multirow{2}{*}{ Nilai C } & \multicolumn{7}{|c|}{ Standar Deviasi (\%) } \\
\cline { 2 - 9 } & $1-1$ & $1-2$ & $2-1$ & $2-2$ & $3-1$ & $3-2$ & 4 & Gabungan \\
\hline 0 & 3,29 & 0,43 & 4,84 & 0,82 & 0,58 & 0,66 & 0,77 & 2,49 \\
\hline 0,1 & 0,93 & 0,74 & 1,68 & 1,18 & 0,82 & 1,02 & 1,22 & 0,56 \\
\hline 1 & 0,86 & 0,64 & 2,11 & 1,11 & 0,77 & 0,92 & 1,16 & 0,55 \\
\hline 10 & 0,83 & 0,57 & 2,72 & 1,01 & 0,71 & 0,84 & 1,05 & 0,58 \\
\hline 100 & 0,82 & 0,50 & 3,04 & 0,96 & 0,68 & 0,75 & 0,95 & 0,58 \\
\hline 1000 & 0,77 & 0,48 & 2,94 & 0,88 & 0,64 & 0,73 & 0,88 & 0,53 \\
\hline 10000 & 0,73 & 0,45 & 2,60 & 0,84 & 0,62 & 0,70 & 0,85 & 0,54 \\
\hline 100000 & 0,68 & 0,44 & 2,12 & 0,83 & 0,61 & 0,68 & 0,82 & 0,51 \\
\hline 1000000 & 0,66 & 0,43 & 1,69 & 0,83 & 0,59 & 0,67 & 0,78 & 0,48 \\
\hline 10000000 & 0,60 & 0,43 & 1,36 & 0,83 & 0,59 & 0,67 & 0,77 & 0,46 \\
\hline
\end{tabular}

TABLE IX

SENSITIFITY AKURASI SISTEM ELM PADA NILAI C TERTENTU

\begin{tabular}{|c|c|c|c|c|c|c|c|c|}
\hline \multirow{2}{*}{ Nilai C } & \multicolumn{8}{|c|}{ Sensitivity (\%) } \\
\cline { 2 - 9 } & $1-1$ & $1-2$ & $2-1$ & $2-2$ & $3-1$ & $3-2$ & 4 & Gabungan \\
\hline 0 & 93,92 & 96,53 & 91,09 & 90,20 & 99,09 & 98,34 & 91,09 & 84,09 \\
\hline 0,1 & 80,30 & 90,58 & 49,09 & 81,19 & 99,64 & 95,23 & 71,87 & 91,83 \\
\hline 1 & 81,28 & 93,38 & 54,17 & 84,83 & 98,97 & 96,28 & 81,38 & 84,73 \\
\hline 10 & 83,55 & 94,98 & 61,37 & 86,66 & 98,77 & 97,05 & 85,94 & 81,99 \\
\hline 100 & 88,17 & 95,83 & 67,38 & 87,46 & 98,88 & 97,80 & 88,77 & 82,19 \\
\hline 1000 & 90,67 & 96,34 & 73,38 & 88,67 & 99,00 & 98,11 & 90,42 & 82,58 \\
\hline 10000 & 92,41 & 96,47 & 77,86 & 89,63 & 99,01 & 98,17 & 90,92 & 82,99 \\
\hline 100000 & 93,29 & 96,50 & 81,58 & 90,02 & 98,98 & 98,17 & 90,99 & 83,63 \\
\hline
\end{tabular}




\begin{tabular}{|c|c|c|c|c|c|c|c|c|}
1000000 & 93,68 & 96,53 & 84,48 & 89,98 & 99,05 & 98,29 & 91,03 & 83,90 \\
\hline 10000000 & 94,07 & 96,53 & 87,32 & 89,96 & 99,12 & 98,36 & 91,02 & 84,08 \\
\hline
\end{tabular}

TABLE $X$

SPECIFICITY AKURASI SISTEM ELM PADA NILAI C TERTENTU

\begin{tabular}{|c|c|c|c|c|c|c|c|c|}
\hline \multirow{2}{*}{ Nilai C } & \multicolumn{7}{|c|}{ Specificity $(\%)$} \\
\cline { 2 - 9 } & $1-1$ & $1-2$ & $2-1$ & $2-2$ & $3-1$ & $3-2$ & 4 & Gabungan \\
\hline 0 & 95,79 & 97,15 & 93,08 & 91,22 & 98,38 & 97,98 & 92,46 & 80,82 \\
\hline 0,1 & 84,33 & 92,19 & 57,83 & 81,37 & 94,57 & 92,71 & 78,13 & 73,31 \\
\hline 1 & 85,74 & 94,10 & 63,11 & 84,95 & 96,04 & 95,03 & 84,90 & 72,67 \\
\hline 10 & 87,60 & 95,59 & 68,96 & 87,26 & 97,18 & 96,44 & 88,39 & 73,86 \\
\hline 100 & 90,50 & 96,48 & 74,56 & 88,36 & 97,81 & 97,34 & 90,71 & 75,33 \\
\hline 1000 & 92,37 & 96,97 & 80,06 & 89,53 & 98,12 & 97,74 & 91,97 & 76,59 \\
\hline 10000 & 93,92 & 97,12 & 83,97 & 90,43 & 98,22 & 97,82 & 92,33 & 77,30 \\
\hline 100000 & 94,76 & 97,14 & 86,83 & 90,87 & 98,24 & 97,82 & 92,31 & 77,99 \\
\hline 1000000 & 95,23 & 97,15 & 89,00 & 90,91 & 98,24 & 97,85 & 92,32 & 78,71 \\
\hline 10000000 & 95,64 & 97,15 & 90,84 & 90,92 & 98,35 & 97,99 & 92,41 & 79,61 \\
\hline
\end{tabular}

TABLE XI

LAMA WAKTU LatiH SISTEM ELM PADA Nilai C TERTENTU

\begin{tabular}{|c|c|c|c|c|c|c|c|c|}
\hline \multirow{2}{*}{ Nilai C } & \multicolumn{9}{|c|}{ Lama Waktu latih (s) } \\
\cline { 2 - 9 } & $1-1$ & $1-2$ & $2-1$ & $2-2$ & $3-1$ & $3-2$ & 4 & Gabungan \\
\hline 0 & 0,86 & 0,82 & 0,86 & 0,81 & 0,82 & 0,82 & 0,79 & 5,98 \\
\hline 0,1 & 0,83 & 0,82 & 0,83 & 0,82 & 0,82 & 0,82 & 0,80 & 5,78 \\
\hline 1 & 0,83 & 0,82 & 0,83 & 0,83 & 0,82 & 0,82 & 0,80 & 5,78 \\
\hline 10 & 0,83 & 0,82 & 0,83 & 0,82 & 0,82 & 0,82 & 0,80 & 5,78 \\
\hline 100 & 0,83 & 0,83 & 0,83 & 0,82 & 0,82 & 0,82 & 0,79 & 5,80 \\
\hline 1000 & 0,83 & 0,82 & 0,83 & 0,82 & 0,82 & 0,82 & 0,79 & 5,78 \\
\hline 10000 & 0,83 & 0,83 & 0,83 & 0,82 & 0,82 & 0,82 & 0,79 & 5,78 \\
\hline 100000 & 0,83 & 0,82 & 0,83 & 0,82 & 0,82 & 0,82 & 0,79 & 5,78 \\
\hline 1000000 & 0,83 & 0,82 & 0,83 & 0,82 & 0,82 & 0,82 & 0,80 & 5,78 \\
\hline 10000000 & 0,83 & 0,82 & 0,83 & 0,82 & 0,82 & 0,82 & 0,80 & 5,80 \\
\hline
\end{tabular}

Pada Tabel VII, IX, dan X terlihat semakin besar nilai C, yang berarti semakin kecil nilai konstan yang ditambahkan ke dalam diagonal dari ELM feature Mapping akurasi, specificity, dan sensitivity dari sistem cenderung semakin meningkat. Rata-rata akurasi terbaik sendiri didapatkan pada seluruh data kecuali data saat tidak ditambahkan nilai konstan apapun atau nilai I/C adalah 0 kecuali untuk data 3-2. Pada data 1-2 sendiri akurasi pada nilai $\mathrm{C}$ yang sangat besar yaitu 1E+06 dan 1E+07 dapat mencapai nilai akurasi yang hampir sama dengan saat nilai konstan sama dengan 0 yaitu 97,95\%. Hal ini juga terjadi pada data 3-2 dimana akurasi sama-sama mencapai $97,60 \%$ pada nilai C $1 \mathrm{E}+07$ dan saat nilai konstan diset sama dengan nol, dengan akurasi $1 \mathrm{E}+07$ sedikit lebih tinggi dengan perbedaan $0,005 \%$. Walaupun rata-rata akurasi yang didapat cukup tinggi pada cross validation namun tidak menambahkan nilai konstan sama sekali dapat berdampak pada stabilitas sistem yang berkurang. Pada satu data 1-1 Standar deviasi akurasi sistem yang menggunakan nilai konstan 0 memiliki standar deviasi yang cukup tinggi dibanding saat menggunakan nilai konstan yang sangat kecil sekalipun. Pada data 1-1 dengan nilai C 1E+07 hanya memiliki standar deviasi $0,6 \%$, sedangkan saat konstanta diset menjadi 0, standar deviasi meningkat jauh hingga 3,29\%. Hal ini juga terjadi pada 2-1 dan data gabungan. Oleh karena itu lebih baik menggunakan nilai konstan yang kecil. Selain didapatkan sistem dengan stabilitas lebih baik dengan standar deviasi yang lebih kecil, juga tidak menurunkan performansi sistem terlalu banyak dari segi akurasi, sensitivity, dan specificity, mengingat pada beberapa 
Ersa Christian Prakoso et.al.

kasus seperti pada data 3-2 sensitivity dan specificity tertinggi didapat pada saat nilai C 1E+07, lebih tinggi daripada saat tidak ditambahkan nilai konstan tertentu.

Untuk pengaruh waktu latih dari perubahan nilai C sendiri, terlihat pada tabel XI bahwa perubahannya tidak banyak mempengaruhi lama waktu latih yang dibutuhkan. Pada data yang terpisah seperti data 1-1 hingga 4, dibutuhkan waktu latih yang kurang lebih sama berkisar antara 0,82 hingga 0,83 detik yang kemungkinan dipengaruhi faktor lain dalam komputer saat eksperimen, sedangkan waktu latih dari data gabungan sendiri kurang lebih berada pada nliai 5,78 hingga 5,80. Namun pada saat nilai konstan diset sama dengan nol, kadang terjadi pelonjakan waktu latih seperti yang terjadi pada 1-1, 2-1 dan data gabungan. Pada data 1-1 dan 2-1 waktu latih menjadi 0,86 detik dibandingkan dengan waktu latih pada parameter yang lain yang berkisar antara 0,82 hingga 0,83 detik, sedangkan pada data gabungan waktu latih naik menjadi 5,98 detik dibanding pada parameter lain yang berkisar pada 5,78 hingga 5,80 detik.

\section{Fungsi Aktivasi}

Berikut adalah tabel hasil pengujian pengaruh fungsi aktivasi yang digunakan terhadap sistem klasifikasi yang dibangun dengan mengambil akurasi dan waktu latih tertinggi pada tiap parameter:

TABLE XII

AKURASI SISTEM ELM DENGAN FUNGSI AKTIVASI TERTENTU

\begin{tabular}{|c|c|c|c|c|c|c|c|c|}
\hline Fungsi & \multicolumn{10}{|c|}{ Akurasi Sistem (\%) } \\
\cline { 2 - 9 } Aktivasi & $1-1$ & $1-2$ & $2-1$ & $2-2$ & $3-1$ & $3-2$ & 4 & Gabungan \\
\hline Sigmoid & 95,00 & 97,81 & 89,10 & 91,03 & 97,32 & 97,60 & 93,34 & 74,34 \\
\hline Radbas & 95,80 & 97,95 & 94,07 & 90,72 & 97,09 & 97,41 & 93,23 & 78,94 \\
\hline
\end{tabular}

TABLE XIII

SENSITIFITY SISTEM ELM DENGAN FUNGSI AKTIVASI TERTENTU

\begin{tabular}{|c|c|c|c|c|c|c|c|c|}
\hline Fungsi & \multicolumn{10}{|c|}{ Sensitivity (\%) } \\
\cline { 2 - 9 } Aktivasi & $1-1$ & $1-2$ & $2-1$ & $2-2$ & $3-1$ & $3-2$ & 4 & Gabungan \\
\hline Sigmoid & 93,31 & 96,30 & 81,96 & 90,20 & 99,64 & 98,36 & 91,09 & 91,83 \\
\hline Radbas & 94,07 & 96,53 & 91,09 & 90,02 & 99,01 & 98,17 & 91,03 & 84,71 \\
\hline
\end{tabular}

TABLE XIV

SPECIFITITY SISTEM ELM DENGAN FUNGSI AKTIVASI TERTENTU

\begin{tabular}{|c|c|c|c|c|c|c|c|c|}
\hline Fungsi & \multicolumn{10}{|c|}{ Specificity (\%) } \\
\cline { 2 - 9 } Aktivasi & $1-1$ & $1-2$ & $2-1$ & $2-2$ & $3-1$ & $3-2$ & 4 & Gabungan \\
\hline Sigmoid & 95,00 & 96,96 & 86,81 & 91,22 & 98,38 & 98,36 & 92,46 & 77,53 \\
\hline Radbas & 95,79 & 97,15 & 93,08 & 90,92 & 98,24 & 97,83 & 92,33 & 80,82 \\
\hline
\end{tabular}

TABLE XV

LAMA WAKTU LATIH SISTEM ELM DENGAN FUNGSI AKTIVASI TERTENTU

\begin{tabular}{|c|c|c|c|c|c|c|c|c|}
\hline Fungsi & \multicolumn{10}{|c|}{ Lama Waktu latih (s) } \\
\cline { 2 - 10 } Aktivasi & $1-1$ & $1-2$ & $2-1$ & $2-2$ & $3-1$ & $3-2$ & 4 & Gabungan \\
\hline Sigmoid & 0,82 & 0,83 & 0,86 & 0,83 & 0,82 & 0,82 & 0,80 & 5,98 \\
\hline Radbas & 0,86 & 0,81 & 0,85 & 0,82 & 0,82 & 0,82 & 0,79 & 5,74 \\
\hline
\end{tabular}

Tabel VII menunjukkan bahwa tiap fungsi aktivasi yang digunakan berpengaruh berbeda-beda pada tiap data yang digunakan. Terdapat sistem ELM yang menghasilkan akurasi lebih baik saat menggunakan fungsi aktivasi sigmoid, dan ada juga yang sebaliknya. Pada data 2-1 dan data gabungan bahkan didapatkan akurasi, 
sensitivity, dan specificity yang berbeda cukup signifikan saat menggunakan kedua fungsi aktivasi yang berbeda yaitu $89,10 \% ; 81,96 \%$; 86,81\% untuk sigmoid, dan 94,07\%; 91,09\%; 93,08\% untuk radial basis. Begitu juga dengan waktu latih dari sistem, masing-masing fungsi aktivasi memberikan perilaku yang berbeda pada tiap-tiap data yang ada. Namun fungsi aktivasi sigmoid cenderung menghasilkan waktu latih yang lebih tinggi daripada radial basis. Walaupun pada beberapa data, sigmoid tercatat memiliki waktu latih yang lebih tinggi namun perbedaannya dengan waktu latih radial basis pada saat itu tidak terpaut jauh. Namun tidak ada korelasi antara lama waktu latih dari sistem dengan akurasi yang didapat, karena pada data 1-1, 1-2, 2-1 dan gabungan yang menggunakan sistem aktivasi radial basis membutuhkan waktu latih yang lebih rendah dibanding sigmoid namun didapat akurasi yang lebih baik. Sedangkan pada data lainnya, walaupun waktu latih dari radial basis lebih rendah, namun akurasi dari fungsi aktivasi sigmoid lebih baik dibanding menggunakan radial basis.

\section{E) Analisis Keseluruhan}

Berikut adalah tabel kombinasi parameter yang menghasilkan akurasi terbaik pada masing-masing data:

TABLE XVI

KOMBINASI PARAMETER TERBAIK UNTUK MASING-MASING DATA

\begin{tabular}{|c|c|c|c|c|c|}
\hline Data & $\begin{array}{c}\text { Fungsi } \\
\text { Aktivasi }\end{array}$ & $\begin{array}{c}\text { Jumlah } \\
\text { Hidden } \\
\text { Neuron }\end{array}$ & Nilai C & $\begin{array}{c}\text { Akurasi } \\
(\%)\end{array}$ & $\begin{array}{c}\text { Waktu } \\
\text { Latih (s) }\end{array}$ \\
\hline $1-1$ & Radial Basis & 1000 & 0 & 95,80 & 0,81 \\
\hline $1-2$ & Radial Basis & 1000 & 0 & 97,95 & 0,81 \\
\hline $2-1$ & Radial Basis & 1000 & 0 & 94,07 & 0,85 \\
\hline $2-2$ & Sigmoid & 1000 & 0 & 91,03 & 0,81 \\
\hline $3-1$ & Sigmoid & 1000 & 0 & 97,32 & 0,82 \\
\hline $3-2$ & Sigmoid & 1000 & $1 \mathrm{E}+07$ & 97,60 & 0,82 \\
\hline 4 & Sigmoid & 1000 & 0 & 93,34 & 0,79 \\
\hline Gabungan & Radial Basis & 1000 & 0 & 78,94 & 5,71 \\
\hline
\end{tabular}

Seperti terlihat pada Tabel XVI, saat masing-masing data dilatih dan diuji secara terpisah, sistem dengan kombinasi parameter yang tepat dapat melakukan klasifikasi dengan akurasi yang terhitung baik, yaitu diatas 90\%. Sistem bahkan dapat mencapai akurasi diatas 95\% untuk beberapa data. Hanya data 2-1, 2-2 dan 4 yang tidak mencapai batas $95 \%$. Hal ini diduga karena setiap orang bisa saja dalam kondisi fisik maupun mental yang berbeda pada saat perekaman data. Orang 2 dan 4 terhitung lebih sulit diklasifikasi dibanding orang 1 dan 3 yang dapat mencapai akurasi lebih tinggi. Namun untuk data gabungan yang merupakan pencampuran dari keseluruhan data menjadi satu, akurasi dari sistem turun drastis hingga hanya dapat mencapai 78,80\%. Hal ini menandakan bahwa sistem masih belum dapat digunakan untuk klasifikasi EEG umum secara langsung. Suatu model yang dibangun berdasarkan sinyal EEG satu orang tidak dapat digunakan untuk kasus klasifikasi dari sinyal EEG milik orang yang berbeda. Hal ini bisa diakibatkan pola sinyal EEG masingmasing orang yang berbeda-beda, mengingat tiap data memiliki nilai maksimum, minimum, dan rata-rata yang berbeda di tiap channel. Oleh karena itu perlu dilakukan suatu fitur ekstraksi untuk menyamakan ciri fitur dari kelas yang sama dari data milik orang yang berbeda. Dengan begitu walaupun secara mentah nilai sinyal masing-masing orang berbeda-beda, namun pada kelas yang sama bisa didapatkan suatu ciri yang sama.

Sistem klasifikasi ELM menggunakan metode Random Feature Mapping yang berarti pada setiap proses training dapat menghasilkan model yang benar-benar berbeda satu dengan lain walaupun menggunakan data dan parameter yang sama persis, karena sangat bergantung pada nilai random yang dihasilkan. Namun dari Standar Deviasi akurasi yang didapat dari masing-masing data, terlihat bahwa performansi yang didapat tidak terlalu jauh walaupun bergantung pada nilai acak. Pada nilai $\mathrm{C}$ sama dengan 0, atau tidak ditambahkan 
Ersa Christian Prakoso et.al.

konstanta sama sekali, kadang dapat berdampak stabilitas proses latih ELM yang kurang baik. Seperti yang terjadi data 1-1 dimana pada parameter $\mathrm{C}$ lain standar deviasi dari akurasi pengujian tidak sampai titik 1\%, namun pada saat nilai $\mathrm{C}$ sama dengan 0 , standar deviasi akurasi pengujian sistem meningkat hingga $4 \%$. Peristiwa ini jarang terjadi, karena pada parameter nilai $\mathrm{C}$ sama dengan 0 untuk data lain tidak terjadi hal itu, namun dapat menjadi pertimbangan untuk selalu menggunakan parameter nilai $\mathrm{C}$ walaupun sekecil mungkin untuk mendapatkan stabilitas proses latih sistem yang lebih baik.

\section{KESIMPULAN}

Setelah melakukan perancangan, implementasi, pengujian dan analisis, maka kesimpulan yang dapat diambil dari penelitian ini adalah:

1. Sistem klasifikasi ELM dapat digunakan untuk melakukan klasifikasi keadaan mata berdasarkan sinyal EEG. Akurasi dinilai baik namun hanya jika setiap corpus dilatih dan diuji secara terpisah, terlihat dari akurasi sistem yang mencapai paling tinggi 97,95\% untuk data terpisah, namun hanya dapat mencapai $78,94 \%$ untuk data gabungan.

2. Sistem klasifikasi ELM cocok digunakan untuk melakukan proses training secara real-time karena dalam 1 kali proses latih tidak memakan waktu yang lama, bahkan untuk data yang sangat banyak sekalipun. Untuk data terpisah waktu latih terlama yang dibutuhkan hanya 0,86 detik, sedangkan data gabungan hanya dibutuhkan waktu 5,98 detik.

3. Dengan semakin banyaknya jumlah hidden neuron, maka akurasi sistem akan semakin tinggi, terlihat dari akurasi terbaik selalu didapat pada jumlah hidden neuron 1000 pada seluruh data hingga 97,95\%. Hanya saja perlu dipertimbangkan peningkatan waktu latih dari sistem yang akan digunakan.

4. Tidak menambahkan konstanta pada matriks ELM Feature Mapping menghasilkan sistem dengan akurasi terbaik pada hampir seluruh data kecuali pada data 3-2 dengan akurasi mencapai 97,95\%, namun terkadang dapat berdampak pada stabilitas sistem ELM yang kurang baik, terlihat pada standar deviasi pengujian data 1-1 yang besar hingga mencapai 4\%. Penggunaan parameter C cukup besar dapat menghasilkan sistem dengan akurasi yang tidak banyak menurun namun dengan stabilitas yang lebih baik seperti 1E+07 yang dapat mencapai akurasi yang sama namun dengan standar deviasi yang jauh lebih kecil yaitu hanya sekitar $1 \%$.

5. Fungsi aktivasi memiliki pengaruh masing-masing pada data yang berbeda, contohnya pada data 2-2 sigmoid dapat mencapai akurasi $91,03 \%$ namun radial basis hanya mencapai $90,72 \%$, tetapi pada data $2-1$ sigmoid hanya mencapai akurasi $89,10 \%$ dibanding radial basis yang mencapai $94,07 \%$

6. Dengan didapatkannya model dengan akurasi yang baik dengan waktu latih yang cenderung cepat, algoritma ELM dapat dimanfaatkan untuk sebagai Brain-computer Interface dengan sebelumnya melakukan pelatihan berdasarkan sinyal EEG orang bersangkutan dengan waktu singkat untuk membangun model. Namun karena model dari 1 orang tidak bisa digunakan untuk orang yang berbeda, maka untuk setiap orang yang berbeda yang menggunakan sistem, perlu dilakukan proses latih ulang.

\section{UCAPAN TERIMA KASIH}

Penulis ingin berterima kasih kepada Oliver Roesler yang telah mendonasikan dataset eye-state yang digunakan penulis untuk penelitian ini, dan kepada Lab Artificial Intelligence, Lab Computing, dan Lab Praktikum Informatika Universitas Telkom yang telah meminjamkan komputer untuk uji coba sistem.

\section{REFERENSI}

[1] Chen, L., L. Li, and L. Xiao. "Differences of EEG between Eyes-Open and Eyes-Closed States Based on Autoregressive Method." Journal Of Electronic Science And Technology Of China, 2009: 175-179.

[2] Roesler, Oliver, dan David Suendermann. "A First Step towards Eye State Prediction Using EEG." in Proceedings of International Conference on Applied Informatics for Health and Life Science. Istanbul: Turkey, 2013. 
[3] Huang, Guang-Bin, Qin-Yu Zhu, dan Chee-Kheong Siew. "Extreme Learning Machine: Theory and applications." Neurocomputing 70, 2006: 489-501.

[4] Zheng, Wei-Long, Jia-Yi Zhu, Yong Peng, dan Bao-Liang Lu. "EEG-based emotion classification using deep belief networks." IEEE International Conference on Multimedia and Expo. Chengdu: IEEE, 2014. 1-6.

[5] Naibaho, Vania Cathlin Raissa. Klasifikasi Emosi Melalui Sinyal EEG yang Dihasilkan Otak dengan Menggunakan Discrete Wavelet Transform dan Backpropagation Artificial Neural Network. Undergraduate Thesis, Bandung: Telkom University, 2013.

[6] Suyanto. Artificial Intelligence. Bandung: Informatika Bandung, 2009.

[7] Huang, Guang-Bin, Hongming Zhou, Xiaojian Ding, dan Rui Zhang. "Extreme Learning Machine for Regression and Multiclass Classification." IEEE Transaction on Systems, Man, and Cybernetics, 2012: 513-529.

[8] Tang, Jiexiong, Chenwei Deng, dan Guang-Bin Huang. "Extreme Learning Machine for Multilayer Perceptron." IEEE Transactions on Neural Networks And Learning Systems, 2013: 809 - 821.

[9] Roesler, Oliver, Lucas Bader, Jan Forster, Yoshikatsu Hayashi, Stefan Hebler, dan David Suendermann. "Comparison of EEG Devices for Eye State Classification.” International Conference on Applied Informatics for Health and Life Sciences (AIHLS), Kusadasi, Turkey, 2014.

[10] Wang, Ting, Sheng-Uei Guan, Ka Lok Man, dan T. O. Ting. "Time Series Classifiaction for EEG Eye State Identification based on Incremental Attribute Learning.” International Symposium on Computer, Consumer and Control. Taichung: $2014,2014.158$ 161.

[11] Zhu, Jia-yi, Wei-Long Zheng, Yong Peng, Ruo-Nan Duan, dan Bao-Liang Lu. "EEG-based Emotion Recognition using Discriminative Graph Regularized Extreme Learning Machine.” International Joint Conference on Neural Networks, 2014: 525532.

[12] Peng, Yong, Jia-Yi Zhu, Wei-Long Zheng, dan Bao-Liang Lu. "EEG-based Emotion Recognition with Manifold Regularized Extreme Learning Machine." 36th Annual International Conference of the IEEE Engineering in Medicine and Biology Society, 2014: 974-977.

[13] Huang, Guang-Bin. "What are Extreme Learning Machines? Filling the Gap Between between Frank Rosenblatt's Dream and John von Neumann's Puzzle.” Cognitive Computation 7, 2015: 263-278.

[14] Huang, Gao, Shiji Song, Keyou You, dan Guang-Bin Huang. "Trends in extreme learning machines: A review." Neural Networks, 2015: 32-48. 
